\section{Response of Weeds and Ornamental Plants to Potting Soil Amended with Dried Distillers Grains}

\author{
Rick A. Boydston ${ }^{1}$ and Harold P. Collins \\ U.S. Department of Agriculture-Agricultural Research Service, Vegetable \\ and Forage Crops Research, 24106 North Bunn Road, Prosser, WA 99350
}

\author{
Steven F. Vaughn \\ U.S. Department of Agriculture-Agricultural Research Service, National \\ Center for Agricultural Utilization Research, 1815 North University Street, \\ Peoria, IL 61604
}

Additional index words. containers, natural products, weed control

\begin{abstract}
This research evaluated the use of dried distiller grains with solubles (DDGS) as a soil amendment to suppress weeds in container-grown ornamentals. DDGS is a byproduct of ethanol produced from corn, and developing new uses for DDGS could increase the profitability of ethanol production. Adding DDGS to a commercial pine bark potting mix reduced emergence and growth of common chickweed (Stellaria media) at concentrations of $5 \%$ (by weight) or greater and annual bluegrass (Poa annua) at concentrations of $10 \%$ (by weight) or more. Herbicidal activity of DDGS was maintained in methanol-extracted DDGS. Rosa hybrid 'Red Sunblaze', Phlox paniculata 'Franz Schubert', and Coreopsis auriculata 'Nana' transplanted into potting soil amended with $\mathbf{2 0} \%$ by weight DDGS were severely stunted and nearly all plants died. Plants survived when transplanted into potting soil containing $10 \%$ DDGS by weight, but growth was greatly stunted and flowering of rose and coreopsis was reduced. Addition of $20 \%$ DDGS decreased the $C: N$ ratio from 90:1 to 24:1 for the potting mix and from 23:1 to 10:1 for a soil. The decrease in $\mathrm{C}: \mathrm{N}$ ratio resulted in a twofold increase in microbial respiration at $3 \mathrm{~d}$ and $14 \mathrm{~d}$ of incubation for both the potting mix and soil. As a result of the phytotoxicity observed on ornamentals transplanted into DDGS-amended potting soil, subsequent studies evaluated surface-applied DDGS to suppress weeds. DDGS applied at $400 \mathrm{~g} \cdot \mathrm{m}^{-2}$ or less to the soil surface at transplanting did not reduce emergence or growth of common chickweed or annual bluegrass. DDGS applied at 800 and $1600 \mathrm{~g} \cdot \mathrm{m}^{-2}$ to the surface of transplanted ornamentals reduced number of annual bluegrass by $40 \%$ and $\mathbf{5 7 \%}$ and common chickweed by $\mathbf{3 3} \%$ and $\mathbf{5 8 \%}$, respectively, without injury to transplanted ornamentals. DDGS may be useful for reducing weed emergence and growth in container-grown ornamentals applied to the soil surface at transplanting.
\end{abstract}

The use of products derived from plant material to control pests appeals to many consumers and nursery operators because there are fewer pesticide residues and worker exposure to pesticides is reduced (McDade and Christians, 2000; Young, 2004). However, poor efficacy or high cost of many natural products have limited their use. Corn gluten meal is a byproduct from corn wet-

\footnotetext{
Received for publication 22 May 2007. Accepted for publication 26 Aug. 2007.

We greatly appreciate the technical assistance of Dallas Spellman, Melanie Copenhaver, and Rebecca Cochran. NW Horticulture Co. kindly provided ornamental plants and potting soil for this research and Big River Resources, LLC, supplied corn dried distillers grains.

Mention of a trademark, proprietary product, or vendor does not constitute a guarantee or warranty of the product by the U.S. Department of Agriculture and does not imply its approval to the exclusion of other products or vendors that also may be suitable.

${ }^{1}$ To whom reprint requests should be addressed; e-mail rick.boydston@ars.usda.gov
}

milling and has been used to control weeds in turf and other crops (Liu et al., 1994; Liu and Christians, 1997; McDade and Christians, 2001; Nonnecke and Christians, 1993). Five dipeptides present in corn gluten meal have been identified that are responsible for the herbicidal effect (Liu and Christians, 1994, 1997)

Another byproduct of ethanol production with potential herbicidal activity is dried distiller grains with solubles (DDGS) which is commonly used as cattle feed. Developing new uses for DDGS could increase the overall profitability of ethanol produced from corn. DDGS typically consist of $10 \%$ moisture, $27 \%$ crude protein, $11 \%$ fat, and nol/ethanol_11.html $>$ ) and typically contains $4.4 \% \mathrm{~N}-0.16 \% \mathrm{P}-0.79 \% \mathrm{~K}$, and $0.5 \% \mathrm{~S}$ in our laboratory testing. The high nitrogen content of DDGS makes it appealing as a potential fertilizer supplement in nursery production.

Preliminary research found that DDGS when applied as a surface mulch (Vaughn, $9 \%$ fiber (<http://www.iowacorn.org/ethainhibited growth of several plant species unpublished data). The research reported here determined the effect of DDGS on two common weed species and three transplanted perennial ornamentals when it was added to pine bark potting mix and when it was applied to the surface of potting soil. Separate experiments evaluated potential causes of the herbicidal effect and measured the effect of DDGS on microbial respiration. Methanolextractable compounds present in DDGS are being evaluated for other value-added uses, so additional experiments were conducted to determine whether the herbicidal properties of DDGS are maintained after methanol extraction.

\section{Materials and Methods}

DDGS were obtained from a commercial ethanol plant near West Burlington, IA (Big River Resources, LLC). Commercial potting mix consisting of $40 \%$ pine bark, $40 \%$ peatmoss, and $20 \%$ pumice (by volume) was obtained from commercial wholesale nursery and greenhouse operator in Mabton, WA (Northwest Horticulture).

Potting soil amended with dried distiller grains with solubles. Greenhouse-grown, 2.5 -cm plugs of coreopsis, Coreopsis auriculata 'Nana', Rosa hybrid 'Red Sunblaze', and Phlox paniculata 'Franz Schubert' were transplanted into $7.5-\mathrm{L}$ pots filled with potting mix containing $0 \%, 10 \%$, and $20 \%$ DDGS (by weight). Rates were selected based on preliminary trials that established that growth of two annual weeds was substantially suppressed in potting mix containing $10 \%$ and $20 \%$ DDGS (by weight). After transplanting, pots were placed in a greenhouse maintained at 20 to $29^{\circ} \mathrm{C}$ and watered daily as needed. Injury to ornamental plants, plant height, and flowering were evaluated at 2, 4, 6, and 8 weeks after transplanting (WAT). Injury was rated on a scale of $0=$ no injury to $10=$ dead. Treatments were replicated five times in a completely randomized design and the experiment was repeated.

In separate studies, 20 seed of annual bluegrass (Poa annua) and common chickweed (Stellaria media) were seeded on the surface of 7.5 -L pots containing $0 \%, 1.25 \%$, $2.5 \%, 5 \%, 10 \%$, and $20 \%$ (by weight) DDGSamended potting mix. Containers were placed in a greenhouse and watered daily as needed. Number of weeds emerged and weed height were evaluated at 2, 4, and 8 weeks after planting (WAP). Weeds were clipped at the soil surface at 8 WAP and weighed. Treatments were replicated five times in a completely randomized design and the experiment was repeated.

Activity of methanol-extracted dried distiller grains with solubles. DDGS were extracted sequentially with hexane using a Soxhlet apparatus for $24 \mathrm{~h}$ followed by Soxhlet extraction for $24 \mathrm{~h}$ using anhydrous methanol $(\mathrm{MeOH})$. The extracted DDGS was dried for $24 \mathrm{~h}$ in an oven at $50{ }^{\circ} \mathrm{C}$ to remove all trace solvents. Twenty seed of common chickweed were planted onto the surface of $0.5-\mathrm{L}$ pots filled with potting mixed containing 
Table 1. Height, number of flowers and flower buds, and phytotoxicity rating on rose, phlox, and coreopsis at 8 weeks after transplanting into potting soil amended with DDGS.

\begin{tabular}{|c|c|c|c|c|c|c|c|c|c|}
\hline \multirow[b]{2}{*}{$\begin{array}{l}\text { Percent DDGS } \\
\text { (by wt.) }\end{array}$} & \multicolumn{3}{|c|}{ Rose Red Sunblaze } & \multicolumn{3}{|c|}{ Phlox Franz Schubert } & \multicolumn{3}{|c|}{ Coreopsis Nana } \\
\hline & $\begin{array}{l}\mathrm{Ht} \\
(\mathrm{cm})\end{array}$ & $\begin{array}{c}\text { Flowers and buds } \\
\text { (no./pot) }\end{array}$ & $\begin{array}{c}\text { Phytotoxicity }^{y} \\
(0-10)\end{array}$ & $\begin{array}{l}\mathrm{Ht} \\
(\mathrm{cm})\end{array}$ & $\begin{array}{c}\text { Flowers and buds } \\
\text { (no./pot) }\end{array}$ & $\begin{array}{c}\text { Phytotoxicity } \\
(0-10)\end{array}$ & $\begin{array}{l}\mathrm{Ht} \\
(\mathrm{cm})\end{array}$ & $\begin{array}{c}\text { Flowers and buds } \\
\text { (no./pot) }\end{array}$ & $\begin{array}{c}\text { Phytotoxicity } \\
(0-10)\end{array}$ \\
\hline 0 & $19.0 \mathrm{a}^{\mathrm{z}}$ & $9.0 \mathrm{a}$ & $0 \mathrm{c}$ & $25.7 \mathrm{a}$ & $0.4 \mathrm{a}$ & $0 \mathrm{c}$ & $10.8 \mathrm{a}$ & $12.6 \mathrm{a}$ & $0 \mathrm{c}$ \\
\hline 10 & $10.8 \mathrm{~b}$ & $1.1 \mathrm{~b}$ & $5.9 \mathrm{~b}$ & $18.5 \mathrm{~b}$ & $0.4 \mathrm{a}$ & $2.8 \mathrm{c}$ & $6.1 \mathrm{~b}$ & $6.9 \mathrm{~b}$ & $3.4 \mathrm{~b}$ \\
\hline
\end{tabular}

${ }^{\mathrm{z}}$ Means within a column followed by the same letter are not significantly different according to the protected least significant difference test at the $P<0.05$ level. ${ }^{y}$ Phytotoxicity rated on a scale of $0=$ no injury to $10=$ dead.

DDGS $=$ dried distiller grains with solubles.

$0 \%, 5 \%, 10 \%$, and $20 \%$ (by weight) DDGS or DDGS that had been methanol-extracted. Pots were placed in a growth chamber set at $23{ }^{\circ} \mathrm{C}$ with a 16 -h photoperiod and watered daily as needed. The number of chickweed seedlings that emerged and plant height were determined at 2, 4, and 8 WAP. Chickweed plants were clipped at the soil surface and weighed at 8 WAP. Treatments were replicated four times in a completely randomized design and the experiment was repeated.

Surface-applied dried distiller grains with solubles. Greenhouse-grown, 2.5-cm plugs of coreopsis, rose, and phlox were transplanted into 7.5-L pots filled with potting mix described previously. After transplanting, 20 seed of annual bluegrass and common chickweed were seeded on the surface of each pot. DDGS were then applied evenly over the surface of each pot at $0,200,400,800$, and $1600 \mathrm{~g} \cdot \mathrm{m}^{-2}$. Pots were placed outdoors under a $65 \%$ shadecloth and watered daily as needed. Ornamental plant height, number of blooms, phytotoxicity, and weed emergence and height were evaluated at 2, 4, 6, and 8 WAT. Weeds were clipped at the soil surface at 8 WAP and weighed. Treatments were replicated five times in a completely randomized design and the experiment was repeated.

Microbial activity of dried distiller grains with solubles-amended soil and potting mix. Soil and potting mix subsamples (four replicates) were amended with $1.25 \%, 2.5 \%$, $5 \%, 10 \%$, and $20 \%$ DDGS (wt $/ \mathrm{wt}$ ). Soil used in the analyses was collected from the U.S. Department of Agriculture-Agricultural Research Service field site near Paterson, WA. The soil was coarse-grained sand and classified as a mixed mesic Xeric Torripsamments (Quincy series). The field soil was prepared by sieving through a $2-\mathrm{mm}$ screen. Total soil, DDGS, and potting mix organic $\mathrm{C}$ and $\mathrm{N}$ were analyzed by dry combustion on a LECO, CNS-2000 Elemental Analyzer (St. Joseph, MI). Microbial respiration was measured using the static-incubation method (Zibilske, 1994). The soil-DDGS mix was used to evaluate the contribution of DDGS to microbial activity exclusive of the potting mix used in the greenhouse studies. Because the potting mix is composed of $100 \%$ organic material, it is subject to microbial decomposition and the release of $\mathrm{CO}_{2}$ after watering. The soil control [low in organic C $(0.23 \%)$ compared with the potting soil (41\%)] allowed us to separate and quantify the contribution of $\mathrm{CO}_{2}$ originating from the potting soil and $\mathrm{CO}_{2}$ originating from the DDGS. The soil control also allowed us to show that the increase in $\mathrm{CO}_{2}$ was the result of the addition of DDGS and not the potting soil.

Soil-DDGS and potting soil-DDGS samples and controls were adjusted to $60 \%$ of field capacity and incubated in $60-\mathrm{mL}$ bottles equipped with rubber septa in the dark at $25^{\circ} \mathrm{C}$ for $14 \mathrm{~d}$. Headspace $\mathrm{CO}_{2}$ was measured at $\approx 2$-d intervals by direct injection of gas samples into an infrared gas analyzer (type

225-MK3; Analytical Development Co. Ltd., Hertfordshire, UK). After analysis, samples were returned to ambient air by degassing with compressed air and adjusted for any moisture loss.

Nitrogen mineralization potentials were determined by incubating three sets of soil samples and potting mix from each amended treatment in $60-\mathrm{mL}$ bottles over 2 weeks at $25{ }^{\circ} \mathrm{C}$ adjusted to $60 \%$ of field capacity. Incubated samples were extracted at weekly intervals with $50 \mathrm{~mL}$ of $1 \mathrm{M} \mathrm{KCl}$, shaken on a rotary shaker for $1 \mathrm{~h}$, and then filtered through

Table 2. Annual bluegrass and common chickweed number of plants per pot and height at 8 weeks after planting into potting soil amended with DDGS.

\begin{tabular}{|c|c|c|c|c|}
\hline \multirow[b]{2}{*}{$\begin{array}{l}\text { Percent DDGS } \\
\text { (by wt.) }\end{array}$} & \multicolumn{2}{|c|}{ Annual bluegrass } & \multicolumn{2}{|c|}{ Common chickweed } \\
\hline & $\begin{array}{l}\text { Seedlings } \\
\text { (no./pot) }\end{array}$ & $\begin{array}{c}\mathrm{Ht} \\
(\mathrm{cm})\end{array}$ & $\begin{array}{l}\text { Seedlings } \\
\text { (no./pot) }\end{array}$ & $\begin{array}{c}\mathrm{Ht} \\
(\mathrm{cm})\end{array}$ \\
\hline 0 & $17.4 \mathrm{a}^{\mathrm{z}}$ & $14.9 \mathrm{a}$ & $8.2 \mathrm{a}$ & $10.2 \mathrm{a}$ \\
\hline 1.25 & $17.5 \mathrm{a}$ & $14.1 \mathrm{a}$ & $6.4 \mathrm{ab}$ & $8.1 \mathrm{a}$ \\
\hline 2.5 & $16.9 \mathrm{a}$ & $14.9 \mathrm{a}$ & $8 \mathrm{a}$ & $8.0 \mathrm{a}$ \\
\hline 5 & $16.6 \mathrm{a}$ & $12.9 \mathrm{a}$ & $5 \mathrm{~b}$ & $5.4 \mathrm{~b}$ \\
\hline 10 & $11.7 \mathrm{~b}$ & $5.2 \mathrm{~b}$ & $1 \mathrm{c}$ & $1.2 \mathrm{c}$ \\
\hline 20 & $0.8 \mathrm{c}$ & $0.5 \mathrm{c}$ & $0 \mathrm{c}$ & $0 \mathrm{c}$ \\
\hline
\end{tabular}

${ }^{\mathrm{z}}$ Means within a column followed by the same letter are not significantly different according to the protected least significant difference test at the $P<0.05$ level.

DDGS $=$ dried distiller grains with solubles

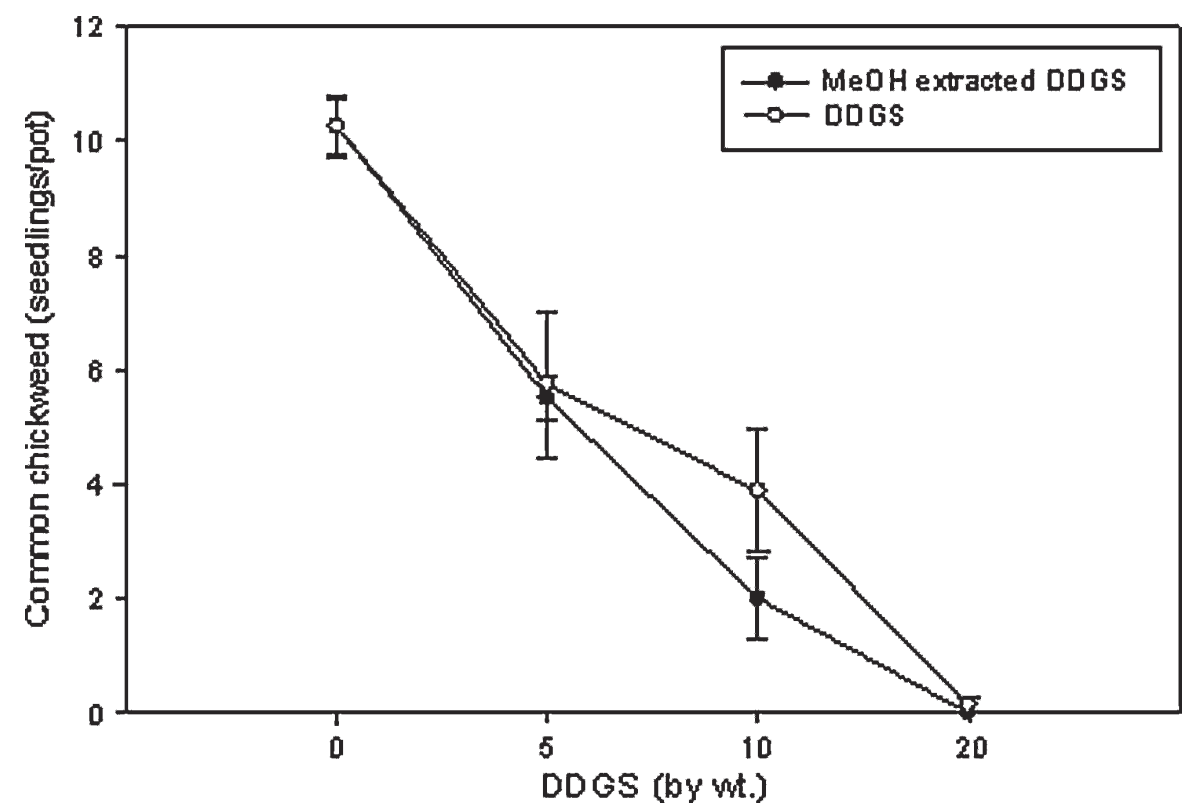

Fig. 1. Number of common chickweed seedlings per pot at 6 weeks after planting into potting soil amended with varying concentrations of dried distiller grains with solubles (DDGS) or anhydrous methanolextracted DDGS. Data are means of eight replications $( \pm \mathrm{SE})$. 
a type $\mathrm{A} / \mathrm{E}$ glass fiber filter (Gelman Sciences, Ann Arbor, MI). The $\mathrm{NO}_{3}-\mathrm{N}$ and $\mathrm{NH}_{4}-\mathrm{N}$ in the extracts was determined on a Lachet FIA 800 Series autoanalyzer (Lachat Zellweger, Loveland, CO).

Soil-DDGS and potting mix $\mathrm{pH}$ were determined using a 2:1 water method. Duplicate 10-g samples of each DDGS treatment were mixed with $20 \mathrm{~mL}$ distilled water in 50-mL centrifuge tubes, capped, and shaken for $5 \mathrm{~min}$ at low speed. After shaking, caps were removed and the slurry allowed to equilibrate for $30 \mathrm{~min}$. Soil $\mathrm{pH}$ was determined using a Fisher Scientific Acumet Basic 15 pH meter (Hampton, NH).

Data from all studies were subjected to analysis of variance (ANOVA) and treatment means separated using the protected least significant difference test at the $P=0.05$ level. Data from separate experiments were combined for analysis when ANOVA indicated that differences between experiments were not significant.

\section{Results and Discussion}

Potting soil amended with dried distiller grains with solubles. Rose, phlox, and coreopsis transplanted into potting soil amended with $10 \%$ or $20 \%$ (by weight) DDGS began to wilt after 1 week and growth was noticeably reduced. All three ornamental species began to develop chlorotic and necrotic leaves at 10 to $14 \mathrm{~d}$ after treatment into potting soil containing 20\% DDGS. Plants transplanted into the soil containing $10 \%$ DDGS survived, but growth was markedly reduced and many plants had necrosis on leaf margins. At 8 WAT, height of roses and coreopsis grown in soil amended with 10\% DDGS was reduced by $43 \%$ and phlox by $28 \%$ compared with plants grown in nonamended soil (Table 1). Bloom of roses and coreopsis transplanted into soil containing $10 \%$ DDGS was also greatly reduced at 8 WAT compared with roses grown in nonamended soil (Table 1). All roses were dead and nearly all phlox and coreopsis were dead at 8 WAT into potting soil amended with 20\% DDGS (Table 1).

Annual bluegrass grown in soil amended with DDGS at concentrations of $10 \%$ or more and common chickweed grown in soil amended with DDGS at concentrations of $5 \%$ or above were chlorotic and shorter than seedlings grown in nonamended potting soil. DDGS added to potting soil reduced the emergence and height of annual bluegrass at 8 WAP when added at rates of $10 \%$ or $20 \%$, but not at rates of $5 \%$ or less (Table 2 ). Most annual bluegrass was dead or severely stunted by DDGS at $20 \%$. The dose required to reduce the number of annual bluegrass and height at 8 WAP by $50 \%$ was 10.9 and $9.7 \%$ DDGS, respectively (Table 2).

Adding DDGS to potting soil appeared to inhibit common chickweed emergence and growth to a greater extent than annual bluegrass. Common chickweed emergence and growth was reduced by DDGS added to potting soil at rates at or above $5 \%$ by weight (Table 2). The dose required to reduce the
Table 3. Height, number of flowers and flower buds, and phytotoxicity rating on rose, phlox, and coreopsis at 8 weeks after transplanting into potting soil amended with surface applied DDGS at 200 to $1600 \mathrm{~g} \cdot \mathrm{m}^{-2}$.

\begin{tabular}{|c|c|c|c|c|c|c|c|c|}
\hline \multirow[b]{3}{*}{$\begin{array}{l}\text { DDGS } \\
\left(\mathrm{g} \cdot \mathrm{m}^{-2}\right)\end{array}$} & \multicolumn{3}{|c|}{ Rose Red Sunblaze } & \multirow{2}{*}{\multicolumn{2}{|c|}{$\begin{array}{c}\text { Phlox Franz } \\
\text { Schubert }\end{array}$}} & \multicolumn{3}{|c|}{ Coreopsis Nana } \\
\hline & \multirow[b]{2}{*}{$\begin{array}{l}\mathrm{Ht} \\
(\mathrm{cm})\end{array}$} & \multirow{2}{*}{$\begin{array}{l}\text { Flowers } \\
\text { and buds } \\
\text { (no./pot) }\end{array}$} & \multirow[b]{2}{*}{$\begin{array}{l}\text { Phytotoxicity } \\
\qquad(0-10)\end{array}$} & & & \multirow[b]{2}{*}{$\begin{array}{c}\mathrm{Ht} \\
(\mathrm{cm})\end{array}$} & \multirow{2}{*}{$\begin{array}{l}\text { Flowers } \\
\text { and buds } \\
\text { (no./pot) }\end{array}$} & \multirow[b]{2}{*}{$\begin{array}{c}\text { Phytotoxicity } \\
(0-10)\end{array}$} \\
\hline & & & & $\begin{array}{l}\mathrm{Ht} \\
(\mathrm{cm})\end{array}$ & $\begin{array}{c}\text { Phytotoxicity } \\
(0-10)\end{array}$ & & & \\
\hline 0 & $13.4 \mathrm{a}^{\mathrm{z}}$ & $3.9 \mathrm{a}$ & 0 & $27.9 \mathrm{a}$ & 0 & $9.9 \mathrm{a}$ & $2.3 \mathrm{a}$ & 0 \\
\hline 200 & $13.1 \mathrm{a}$ & $4.4 \mathrm{a}$ & 0 & $29.1 \mathrm{a}$ & 0 & $11.6 \mathrm{a}$ & $5.6 \mathrm{a}$ & 0 \\
\hline 400 & $12.9 \mathrm{a}$ & $4.8 \mathrm{a}$ & 0 & $30.6 \mathrm{a}$ & 0 & $8.4 \mathrm{a}$ & $5.0 \mathrm{a}$ & 0 \\
\hline 800 & $13.8 \mathrm{a}$ & $6.4 \mathrm{a}$ & 0 & $28.3 \mathrm{a}$ & 0 & $9.2 \mathrm{a}$ & $4.4 \mathrm{a}$ & 0 \\
\hline 1600 & $12.7 \mathrm{a}$ & $6.2 \mathrm{a}$ & 0 & $29.3 \mathrm{a}$ & 0 & $8.5 \mathrm{a}$ & $5.0 \mathrm{a}$ & 0 \\
\hline
\end{tabular}

${ }^{z}$ Means within a column followed by the same letter are not significantly different according to the protected least significant difference test at the $P<0.05$ level.

y Phytotoxicity rated on a scale of $0=$ no injury to $10=$ dead.

DDGS $=$ dried distiller grains with solubles.
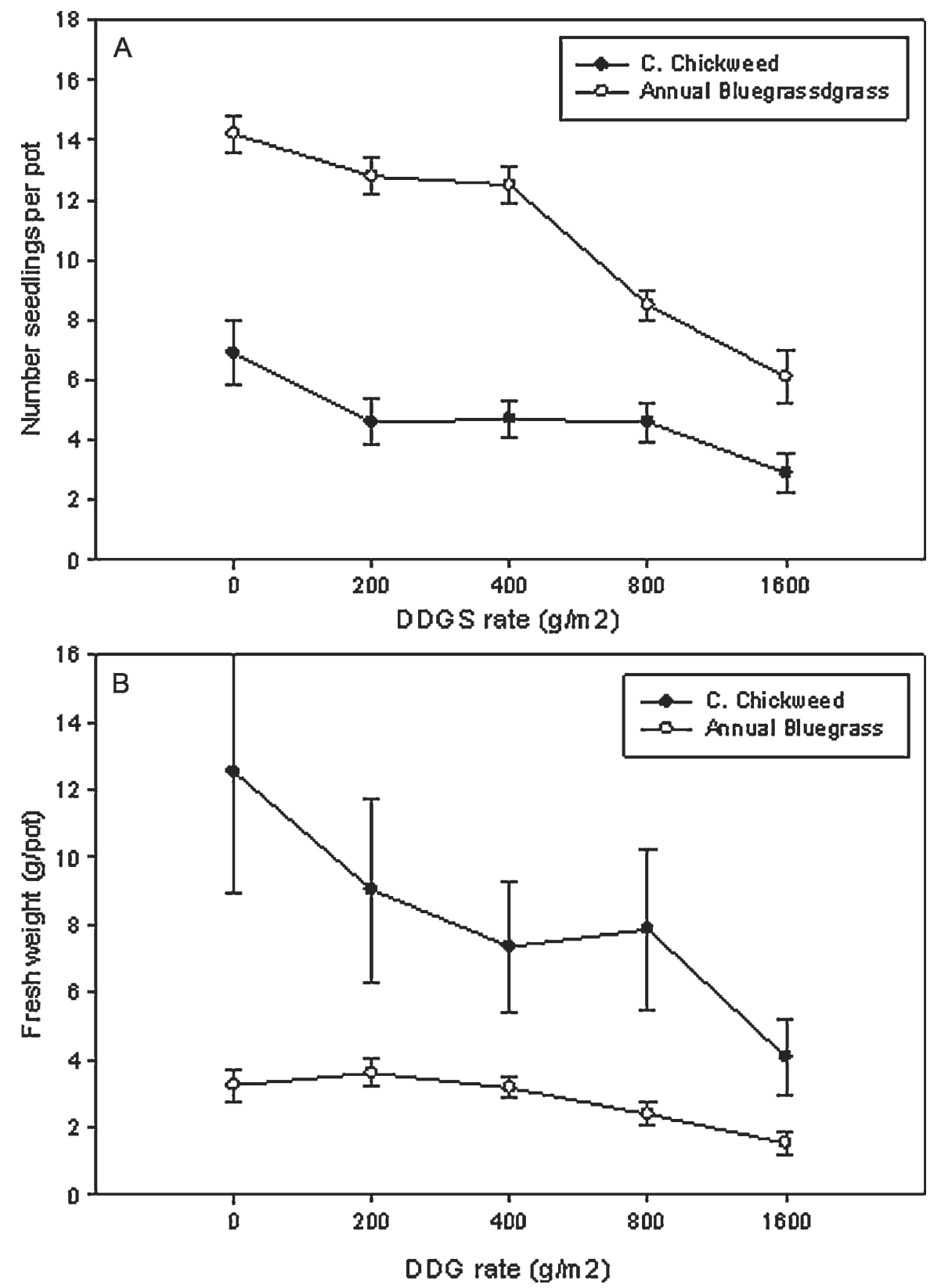

Fig. 2. Number of (A) seedlings and (B) fresh weight of common chickweed and annual bluegrass 8 weeks after planting in pots amended with surface applied dried distiller grains with solubles at four concentrations. Data are the means of 10 replications $( \pm \mathrm{SE})$. 
number of common chickweed and height at 8 WAP by $50 \%$ was $3.5 \%$ and $4.3 \%$ DDGS, respectively. Nearly all common chickweed failed to emerge or grow in soil amended with $10 \%$ DDGS and no common chickweed survived in soil amended with 20\% DDGS (Table 2).

Activity of methanol-extracted dried distiller grains with solubles. $\mathrm{MeOH}-$ extracted DDGS added to potting soil inhibited emergence and growth of common chickweed similar to DDGS (Fig. 1). Common chickweed that emerged in soil amended with DDGS or $\mathrm{MeOH}$-extracted DDGS at concentrations of $5 \%(\mathrm{wt} / \mathrm{wt})$ or more were chlorotic and shorter than seedlings grown in nonamended potting soil. Nearly all common chickweed failed to emerge or grow in soil amended with $10 \%$ (by weight) DDGS or $\mathrm{MeOH}$-extracted DDGS and no common chickweed survived in soil-amended with $20 \%$ (by weight) of either material (Fig. 1). Apparently, inhibitory compounds in DDGS were not removed by Soxhlet extraction with $\mathrm{MeOH}$.

Surface-applied dried distiller grains with solubles. DDGS applied to the soil surface at 200 to $1600 \mathrm{~g} \cdot \mathrm{m}^{-2}$ immediately after transplanting ornamentals did not affect the growth, flowering, or appearance of rose, phlox, or coreopsis at 8 WAT (Table 3). DDGS applied to the soil surface at rates of 200 to $800 \mathrm{~g} \cdot \mathrm{m}^{-2}$ failed to reduce final fresh weight of common chickweed compared with nontreated checks (Fig. 2B). However, DDGS applied at $1600 \mathrm{~g} \cdot \mathrm{m}^{-2}$ reduced the number of seedlings and total fresh weight of common chickweed $58 \%$ and $67 \%$, respectively, at 8 WAP (Fig. 2A-B). By 8 WAP, the height of surviving common chickweed seedlings grown in DDGS-amended soil was not reduced compared with seedlings grown in nontreated pots, which averaged $12.8 \mathrm{~cm}$.

DDGS applied to the soil surface at 800 to $1600 \mathrm{~g} \cdot \mathrm{m}^{-2}$ reduced the number of annual bluegrass seedlings $40 \%$ and $57 \%$, respectively, and reduced total fresh weight $27 \%$ and $53 \%$, respectively, at 8 WAP compared with the nontreated checks (Fig. 2A-B). However, annual bluegrass height was only reduced $13 \%$ by the highest rate of 1600 $\mathrm{g} \cdot \mathrm{m}^{-2}$. Lower rates of 200 to $400 \mathrm{~g} \cdot \mathrm{m}^{-2}$ DDGS did not significantly reduce the number of annual bluegrass seedlings, height, or fresh weight at 8 WAP compared with the nontreated checks (Fig. 2A-B).

Microbial analyses of dried distiller grains with solubles-amended soil and potting mix. Amendments of DDGS reduced the $\mathrm{pH}$ of the amended soil, averaging 0.4 units for each doubling of DDGS (Table 4). Soil pH decreased 2.0 units, from 6.5 to 4.5 with a $20 \%$ amendment, in contrast to the potting mix, which decreased only 0.2 units (pH 5.0 to 4.8). Total $\mathrm{C}$ and $\mathrm{N}$ contents were $407.5 \mathrm{~g} \cdot \mathrm{kg}^{-1} \mathrm{C}$ and $4.5 \mathrm{~g} \cdot \mathrm{kg}^{-1} \mathrm{~N}$ for the nonamended potting mix and $2.3 \mathrm{~g} \cdot \mathrm{kg}^{-1} \mathrm{C}$ and $0.1 \mathrm{~g} \cdot \mathrm{kg}^{-1} \mathrm{~N}$ for the nonamended soil, respectively. On addition of DDGS, $\mathrm{N}$ content increased by an average factor of 1.4 for each doubling of the DDGS amendment reaching a high of $18.2 \mathrm{~g} \cdot \mathrm{kg}^{-1} \mathrm{~N}$ in the $20 \%$ amended potting mix. In soil, the increase in $\mathrm{N}$ was by a factor of two. Addition of $20 \%$ DDGS decreased the C:N ratio from $90: 1$ to 24:1 for the potting mix and 23:1 to $10: 1$ for the soil. This decrease in $\mathrm{C}: \mathrm{N}$ ratio resulted in a twofold increase in microbial respiration at $3 \mathrm{~d}$ and $14 \mathrm{~d}$ of incubation for both the potting mix and soil and reflected the higher soil temperature (Fig. 3). The increase in microbial respiration doubled the $\mathrm{CO}_{2}$ concentration evolved from the potting mix and soil by $3 \mathrm{~d}$ and nearly tripled in the potting mix by $14 \mathrm{~d}$. Numbers of fungi and bacteria increased three orders of magnitude for the $20 \%$ amended potting mix and soil compared with the nonamended. Fungal populations were $2.3 * 10^{6}, 5.9^{*} 10^{8}, 7.3 * 10^{8}$, and $5.4 * 10^{9}$, colony-forming units (CFUs) for the $0 \%, 5 \%$, $10 \%$, and $20 \%$ amended potting mix, respectively, in which bacterial populations over the same treatments ranged between $5.5^{*} 10^{3}$ to $2.0^{*} 10^{7}$ CFUs. Nitrogen was mineralized in potting soil amended with $2.5 \%$ or less DDGS and was immobilized in potting soil amended with $5 \%, 10 \%$, or $20 \%$ DDGS (Fig. 4).

\section{Summary}

DDGS mixed in potting soil was phytotoxic to transplanted rose, phlox, and coreopsis and to seeded annual bluegrass and common chickweed at rates of $10 \%$ (by weight) or more. The cause of the phytotoxicity was not determined, but as shown by the increase in microbial activity, the DDGS was likely used as a nutrient source by resident soil microbial populations resulting in the possible release of toxic degradation products, including an increase in $\mathrm{CO}_{2}$ and a reduction in soil oxygen. In addition, an $11{ }^{\circ} \mathrm{C}$ rise in average soil temperature (Fig. 3) was

Table 4. Total C, N, pH, and microbial respiration of DDGS-amended potting mix and soil.

\begin{tabular}{|c|c|c|c|c|c|c|}
\hline \multirow{3}{*}{$\begin{array}{l}\text { Amendment } \\
\text { Distillers grain } \\
\text { PM-DDGS mix }\end{array}$} & \multirow{3}{*}{$\frac{\mathrm{pH}}{4.3}$} & $\begin{array}{c}\text { Total C } \\
\mathrm{g} \cdot \mathrm{kg}^{-1}\end{array}$ & $\begin{array}{c}\text { Total N } \\
\mathrm{g} \cdot \mathrm{kg}^{-1}\end{array}$ & $\mathrm{C}: \mathrm{N}$ & \multicolumn{2}{|c|}{$\begin{array}{c}\text { Microbial respiration } \\
\mathrm{CO}_{2} \\
\mathrm{~g} \cdot \mathrm{kg}^{-1}\end{array}$} \\
\hline & & 494.0 & 41.4 & 11.9 & - & \\
\hline & & & & & $3 \mathrm{~d}^{\mathrm{y}}$ & $14 d^{y}$ \\
\hline 0 & 5.0 & $407.5 \mathrm{a}^{\mathrm{x}}$ & $4.5 \mathrm{a}$ & 90.6 & $11.4 \mathrm{a}$ & $30.6 \mathrm{a}$ \\
\hline 1.25 & 5.0 & $428.5 \mathrm{~b}$ & $5.1 \mathrm{ab}$ & 84.2 & $13.2 \mathrm{~b}$ & $38.1 \mathrm{~b}$ \\
\hline 2.5 & 5.0 & $434.5 \mathrm{~b}$ & $6.0 \mathrm{~b}$ & 72.5 & $16.1 \mathrm{c}$ & $43.6 \mathrm{~b}$ \\
\hline 5.0 & 4.7 & $451.5 \mathrm{~d}$ & $8.5 \mathrm{c}$ & 52.9 & $16.9 \mathrm{c}$ & $52.8 \mathrm{c}$ \\
\hline 10 & 4.8 & $442.5 \mathrm{c}$ & $10.7 \mathrm{~d}$ & 40.1 & $18.7 \mathrm{~d}$ & $93.5 \mathrm{~d}$ \\
\hline 20 & 4.8 & $443.5 \mathrm{c}$ & $18.2 \mathrm{e}$ & 24.4 & $22.7 \mathrm{e}$ & $105.6 \mathrm{e}$ \\
\hline Soil-DDGS mix & & & & & $3 d^{y}$ & $14 d^{y}$ \\
\hline 0 & 6.5 & $2.3 \mathrm{a}$ & $0.1 \mathrm{a}$ & 23.0 & $0.1 \mathrm{a}$ & $0.3 \mathrm{a}$ \\
\hline 1.25 & 5.9 & $9.9 \mathrm{~b}$ & $0.5 \mathrm{~b}$ & 20.6 & $3.7 \mathrm{~b}$ & $13.9 \mathrm{~b}$ \\
\hline 2.5 & 5.5 & $15.7 \mathrm{c}$ & $1.0 \mathrm{c}$ & 15.1 & $5.9 \mathrm{c}$ & $21.5 \mathrm{c}$ \\
\hline 5.0 & 5.1 & $26.9 \mathrm{~d}$ & $2.0 \mathrm{~d}$ & 13.4 & $6.2 \mathrm{~cd}$ & $24.5 \mathrm{~d}$ \\
\hline 10 & 4.8 & $51.0 \mathrm{e}$ & $4.7 \mathrm{e}$ & 10.9 & $6.6 \mathrm{~d}$ & $25.4 \mathrm{~d}$ \\
\hline 20 & 4.5 & $101.0 \mathrm{f}$ & $9.7 \mathrm{f}$ & 10.4 & $7.7 \mathrm{e}$ & $27.3 \mathrm{e}$ \\
\hline
\end{tabular}

${ }^{\text {2PM }}=$ potting mix; DDGS $=$ dried distillers' grain.

${ }^{\mathrm{y}}$ Three and $14 \mathrm{~d}$ of laboratory incubation.

${ }^{x}$ Means within a column followed by the same letter are not significantly different according to the protected least significant difference test at the $P<0.05$ level.

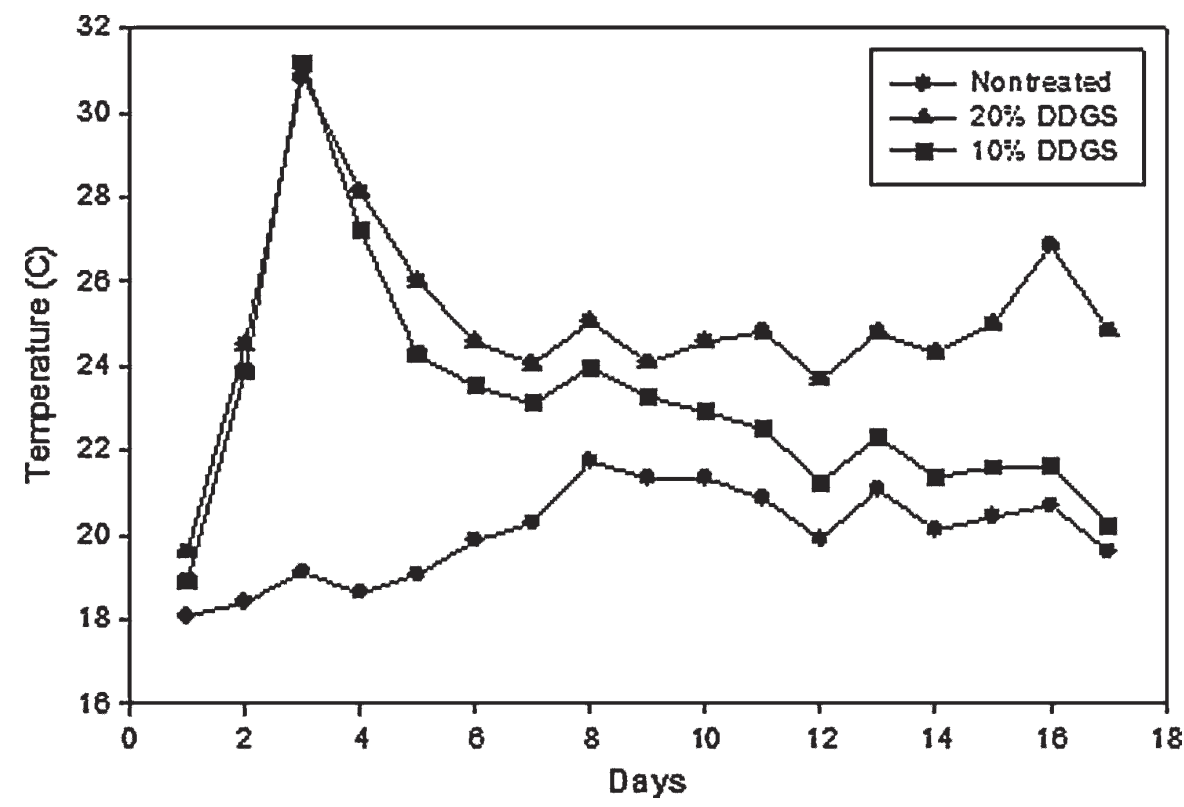

Fig. 3. Average daily soil temperature of greenhouse potting soil amended with dried distiller grains with solubles at $10 \%$ and $20 \%$ (by wt.). 


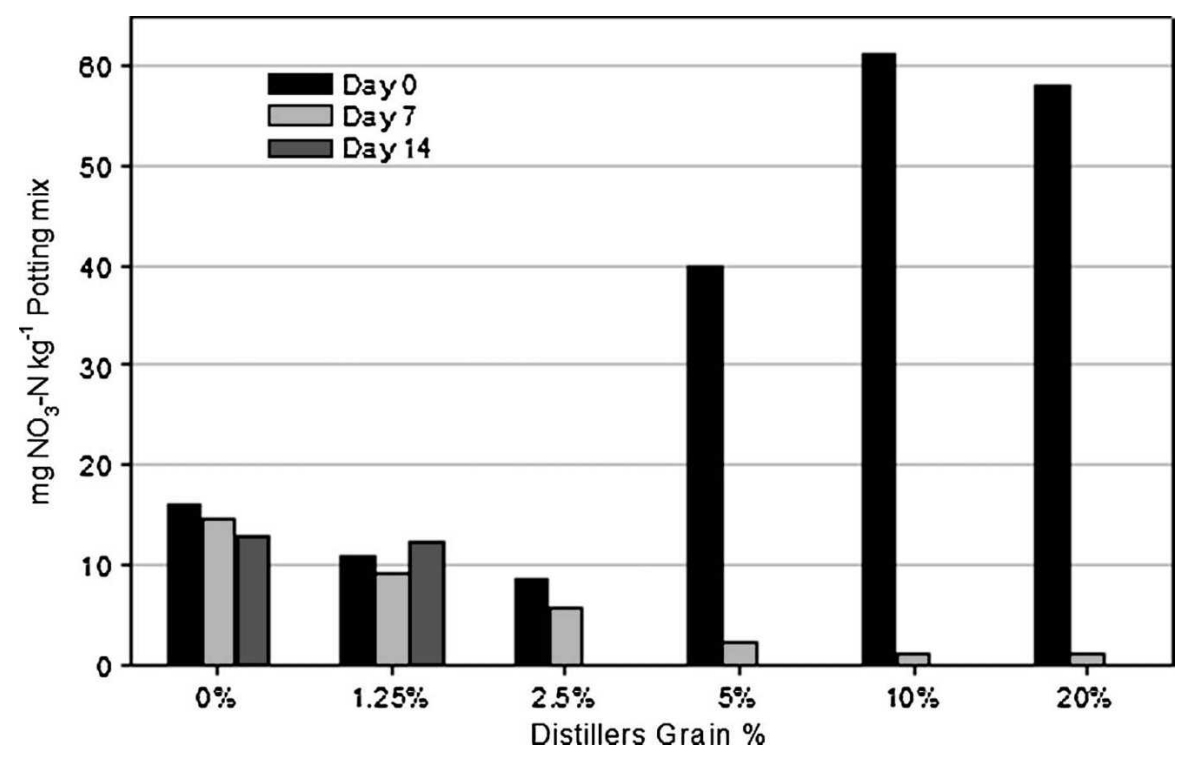

Fig. 4. Nitrogen mineralization for dried distiller grains with solubles-amended potting mix.

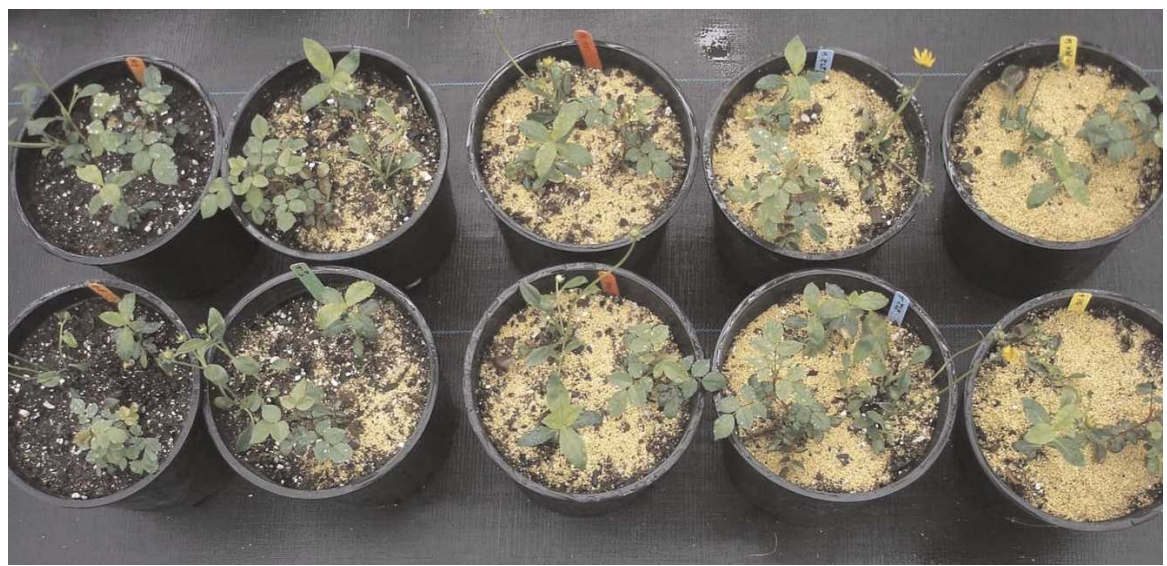

Fig. 5. Container-grown ornamentals amended with $0,100,200,400$, and $800 \mathrm{~g} \cdot \mathrm{m}^{-2}$ dried distiller grains with solubles.

observed at $3 \mathrm{~d}$ after amendment with DDGS and was most likely the result of the doubling of microbial activity as the amount of DDGS increased to $10 \%$ and $20 \%$, similar to the heat generated by the composting process.

Annual bluegrass and common chickweed both germinate readily over the range of soil temperatures recorded, so it is unlikely the observed phytotoxicity of DDGS was a result of the increase in soil temperature (Buhler and Hoffman, 1999).

Corn gluten meal has been reported to suppress 22 germinating weed species at rates of 300 to $1000 \mathrm{~g} \cdot \mathrm{m}^{2}$ (Bingaman and soil proved safe to the transplanted rose, phlox, and coreopsis while reducing the number of weed seedlings able to establish from seed at rates 800 to $1600 \mathrm{~g} \cdot \mathrm{m}^{-2}$. Nearly complete coverage of the soil surface was achieved with DDGS at the two highest rates of 800 and $1600 \mathrm{~g} \cdot \mathrm{m}^{-2}$, which could possibly have some mulching effect (Fig. 5). However, some weed seedlings escaped surface treatment with DDGS indicating that placement of DDGS granules near germinating weed seedlings or emerging roots may be important for maximum efficacy. Testing is underway to determine the timing of transplantation after DDGS amendment or if higher rates of DDGS applied to the soil surface or shallow placement of DDGS may further reduce weed germination and establishment without injuring transplanted ornamentals.

\section{Literature Cited}

Bingaman, B.R. and N.E. Christians. 1995. Greenhouse screening of corn gluten meal as a natural control product for broadleaf and grass weeds. HortScience 30:1256-1259.

Buhler, D.D. and M.L. Hoffman. 1999. Andersen's guide to practical methods of propagating weeds and other plants. Weed Sci. Soc. America, Allen Press, Inc, Lawrence, KS.

Liu, D.L. and N.E. Christians. 1994. Isolation and identification of root-inhibiting compounds from corn gluten hydrolysate. J. Plant Growth Regulat. 13:227-230.

Liu, D.L. and N.E. Christians. 1997. The use of hydrolyzed corn gluten meal as a natural preemergence weed control in turf. Intl. Turfgrass Soc. Res. J. 8:1043-1050.

Liu, D.L., N.E. Christians, and J.T. Garbutt. 1994. Herbicidal activity of a hydrolyzed corn gluten meal on three grass species under controlled environments. J. Plant Growth Regulat. 13:221-226.

McDade, M.C. and N.E. Christians. 2000. Corn gluten meal-A natural preemergence herbicide: Effect on vegetable seedlings survival and weed cover. Amer. J. Altern. Agr. 15:189-191.

Christians, 1995). Although weed suppression is often limited with corn gluten meal application rates below $300 \mathrm{~g} \cdot \mathrm{m}^{-2}$, stands of several direct seeded vegetables were reduced with rates as low as $100 \mathrm{~g} \cdot \mathrm{m}^{-2}$ (McDade and Christians, 2000). Five dipeptides extracted from hydrolyzed corn gluten meal were shown to inhibit root growth of germinating weeds, whereas shoot growth was less affected (Liu and Christians, 1994). Whether the same compounds are responsible for any of the phytotoxicity observed in these studies is not known.

Placing similar amounts of DDGS on the soil surface rather than mixing in the
McDade, M.C. and N.E. Christians. 2001. Corn gluten hydrolysate for crabgrass (Digitaria spp.) control turf. Intl. Turfgrass Soc. Res. J. 9:3-7.

Nonnecke, G.R. and N.E. Christians. 1993. Evaluation of corn gluten meal as a natural, weed control product in strawberry. Acta Hort. 348:315-320.

Young, S.L. 2004. Natural product herbicides for control of annual vegetation along roadsides. Weed Technol. 18:580-587.

Zibilske, L.M. 1994. Carbon mineralization, p. 835-864. In: R.W. Weaver, J.S. Angle, and P.S. Bottomley (eds.). Methods of soil analysis, part 2. Microbiological and biochemical properties. Soil Sci. Soc. Amer, Madison, WI. 